\title{
THE EXAMINATION OF THE RELATIONS OF PERSONAL RESOURCES, TASK SIGNIFICANCE, TRUST IN SUPERVISOR AND PERSON-JOB FIT WITH PERCEIVED WORK ENGAGEMENT: A RESEARCH STUDY IN A SAMPLE OF EMPLOYEES WORKING IN LOCAL AND MULTINATIONAL ORGANIZATIONS
}

Hasan Demirci *

* İstanbul Üniversitesi E-mail: hasandemirci@outlook.fr

Copyright (C) 2015 Hasan Demirci. This is an open access article distributed under the Eurasian Academy of Sciences License, which permits unrestricted use, distribution, and reproduction in any medium, provided the original work is properly cited.

\begin{abstract}
This study aims to examine the role of self-efficacy, resilience, task significance, person-job fit and trust in supervisor on work engagement. The research question is what variables have positive relationship with work engagement. In order to reach accurate results for this research, the data is collected by applying questionnaires to employees about their personal and occupational perception as well as supervisor's attitude and trustworthiness in addition to the employees' work engagement. In addition to these; demographic variables like gender, tenure, age, company experience, total work experience, working in a local or multinational company and education levels are also taken into consideration. The sample of the research consists of 265 employees who work in multinational companies and local firms from different sectors and continuing their master education in Marmara and Istanbul Universities. The analyses are conducted by using SPSS 20.0 program (The Statistical Package for Social Sciences). In this relationship, each of the independent variable mentioned above has positive significant relationship with each of the sub-dimensions of work engagement. The findings also suggest that all the independent variables except resilience when included in analysis together to conduct multiple regression appeared to have positive relationship with work engagement.
\end{abstract}

Keywords: Self-Efficacy, Resilience, Task Significance, Person-Job Fit, Trust in Supervisor, Work Engagement

JEL-Clasification: M19

\section{Bireysel Kaynaklar, İşin Anlamlılığı, Amire Güven ve Birey-İş Uyumluluğunun Algılanan Çalışmaya Tutkunluk ile İlişskilerinin İncelenmesi: Yerli ve Yabancı Organizasyon Çalışanları Üzerinde Bir Araştırma}

\section{ÖZET}

Bu çalışmada, öz-yetkinlik(yeterlilik), dayanıklılık, görev anlamlılı̆̆ı, kişi-iş uyumu ve amire güven değişkenlerinin çalışmaya tutkunluk değişkeni üzerindeki rolünün incelenmesi 
amaçlanmaktadır. Sorunsal ise hangi değişkenlerin çalışmaya tutkunluk değişkeniyle pozitif bir ilişkiye sahip olacağı konusundadır. Güvenilir sonuçlara ulaşmak amacıyla, çalışma verileri yerel ve uluslararsı şirketlerde ve farklı sektörlerde görev alan çalışanlara kişisel ve mesleki algılarının yanısıra amirlerinin tutumu ve güvenilirliği hakkında anketler uygulanmıştır. Bunlara ek olarak; cinsiyet, kademe, yaş, şirket tecrübesi, toplam iş hayatı tecrübesi, yerel veya uluslarası şirketlerde görev alma ve eğitim durumu dikkate alınmıştır. Çalışmanın örneklemi yerel ve uluslarası şirketlerde çalışmakta olup farklı sektörlerde bulunan ve mevcut durumda İstanbul Üniversitesi ve Marmara Üniversitesi'nde yüksek lisans eğitimlerine devam etmekte olan 265 şirket elemanından müteşekkildir.Çalışma verileri SPSS 20.0 programı kullanılarak analiz edilmiştir.Bu bağlamda, yukarıda adı geçen her bir bağımsız değişkenin, çalışmaya tutkunluk değişkeninin alt boyutlarıyla pozitif ilişkiye sahip olduğu tespit edildi. Çalışma bulguları ayrıca dayanıklılık dışındaki tüm bağımsız değişkenlerin, çoklu regresyon analizi yapmak üzere analize birlikte dahil edildiğinde çalışmaya tutkunluk değişkeniyle pozitif ilişkiye sahip olduğu görüldü.

Anahtar Kelimeler: Öz-yetkinlik, Dayanıklılık, İşin Anlamlılığı, Çalışan-İşçi Uyumu, Amire Güven, Çalışmaya Tutkunluk

\section{Introduction}

\section{Literature Review and Conceptual Framework}

\section{o 1.1. Related Concepts to Work Engagement}

The concept of engagement has been introduced and conceptualized as the "harnessing of organization members' selves to their work roles; in engagement, people employ and express themselves physically, cognitively, and emotionally during role performances" (Kahn, 1990, p. 694). Thus, engaged employees put a great deal of effort into their work because they identify themselves with it. Furthermore, he said that engagement is a product of two different forces: an individual's respective psychological experience of work that drives their attitudes and behavior and the individual, interpersonal, group, intergroup and organizational factors that influence this experience. Therefore, engagement is not only a product of one's individual drives, but it is also influenced by outside factors that may or may not motivate one to become engaged in a particular role (Kahn, 1990).

Work engagement refers to the motivational mental state that people experience when they are completely immersed in their work to the extent that time seems to fly by.(Bakker, Schaufeli, Leiter, and Taris, 2008; Bakker, A.B., Schaufeli, W.B., Leiter, M.P., and Taris, T.W. 2008). Among the most often cited definitions of work engagement, as mentioned above, is a state of mind that is characterized by vigor, dedication, and absorption" (Schaufeli et al., 2002, p.74; Hering, Beerlage and Kleiber, 2010). Vigor refers to the level of energy and mental resilience that individuals have towards their work, how willing they are to put effort in and persevere in their work, even in the face of hard times. An individual with high vigor feels motivated at work and keeps performing his task even if $\mathrm{s} / \mathrm{he}$ faces hurdles. Dedication is how involved one is in their work and to what extent they experience feelings of enthusiasm, pride, inspiration, significance, and challenge towards it. Individuals with high dedication think that their job is interesting, requires effort, serves for a purpose and is meaningful; the job they do inspires them, so they do it with enthusiasm and feel proud of it (Turgut, 2011). Absorption is characterized as how concentrated and happily engrossed one is 
in their work. It refers to a feeling akin to flow, where time passes by quickly and people find it difficult to detach themselves from their work.

Among the antecedent of work engagement, task characteristics, role characteristics and work interactions can be counted from a general perspective. More specifically, the antecedents of work engagement in literature are job resources i.e. task significance, autonomy, personal feedback, social support, supervisory coaching, opportunities (Schaufeli and Bakker, 2004), personal resources i.e. hope, optimisim, self-efficacy and resilience (Hornung et al., 2011), person-organization fit (Ünal and Turgut, 2013) as well as person-job fit (Chen, Yen and Tsai, 2014), psychological empowerment (Ugwu, Onyishi and RodriguezSanchez, 2014). In the same vein, learning organizations (Park et al., 2013), organizational structure (Staheli, 2013), organizationalclimate (Ratliff, 2012), organizational trust (Ugwu et. al. 2013) as well as organizational justice (Strom, Sears and Kelly, 2014) have also a positive relationship with perceived work engagement as well as job control/autonomy and social/perceived organizational support (Peccei, 2013; Guest, 2014).As for consequences of work engagement;performance (Kim, Kolb and Kim, 2013), organizational citizenship behavior (OCB) (Roberson and Strickland, 2010), intention to quit (Saks, 2006) and deviant behavior (Shantz et. al., 2013) can be cited.In literature, self-efficacy (Koçak, 2013), task significance (Shantz et. al., 2013), work pressure (Arabac1, 2012) and empowerment (Ugwu et. al. 2013)have been taken into account as moderators of work engagement.

\section{O 1.2. The Job Demands and Resources Theory}

In this section, we will give the definiton and explain the concept of the Job DemandResources (JD-R) Model. We will rely upon this particular theory in order to examine the relationships between self-efficacy and work engagement, resilience and work engagement, task significance and work engagement as well as the relationship between person-job fit and work engagement. Thereby, we will propose the hypotheses of the study.

The Job Demand-Resources (JD-R) Model emerged from principal models like Karasek's JD-C (1979), Hackman and Oldham's Job Characteristics (1975) and Siegrist's ERI (1996) that especially focus on the role of the work environment in terms of employee adapation at work (Koçak, 2013).

Job demands has been defined as "the degree to which the environment contains stimuli that peremptorily require attention and response" (Jones and Fletcher, 1996). Demands are defined as the "things that have to be done." Schaufeli and Bakker (2004) refer to job demands as "those physical, psychological, social or organizational aspects of the job that require sustained physical and/or psychological effort and are consequently associated with certain physiological and/or psychological costs (i.e., strain)."

Whereas job resources "are physical, psychological, social, or organizational features of the job that are functional in achieving work goals. They reduce job demands and the physical and/or psychological costs associated with them (negative responses such as burnout,), and stimulate personal growth and development" (Bakker, Demerouti and Schaufeli, 2003; Hobfoll and Shirom, 2001). Job resources consist of two components. The extrinsic component is related to social and organizational factors, while the intrinsic component is related to physical and psychological factors. Job resources are necessary to deal with job demands and to get things done (Hobfoll, 2002). Yet an undesirable 
relationship between these components can lead to work overload, exhaustion, disengagement, and ultimately dissatisfaction (Criscitelli, 2014).

The Job Demands and Resources model is based upon the assumption that when job demands are high and job resources are limited, work engagement level reduces. Job demands are direct initiators of the health impairment process and job resources are direct initiators of the motivational process (Demerouti and Bakker, 2011). Demands and resources are interrelated, and create certain outcomes ranging from positive well-being and motivation to continual exhaustion and dormant burnout (Jonge, Le Blanc, Peeters, and Noordam, 2008; Leiter, 2008). A positive relationship between demands and resources leads to positive work engagement. This can enhance one's ability to meet goals, besides inspiring personal growth, learning, and development (Bakker and Demerouti, 2008).

High job demands and high job resources such as shared support and performance evaluation leads to work engagement, institutional commitment, and high levels of motivation (Rodriquez-Munoz, Sanz-Vergel, Demerouti, and Bakker, 2012). Common job resources that have been studied in work engagement literature involve social support (i.e., from supervisors, coworkers, friends, and family), performance feedback, rewards, autonomy supervisor coaching, and opportunities for professional development (Taştan, 2014). Bakker (2011) suggested that social support for managers and colleagues, performance feedback, variety in skills performed, and autonomy spark the motivational process. Motivation leads to engagement and a higher level of performance. Bakker also found that when employees are challenged by high job demands, they focus more on job resources and their motivation increases along the process.

Based on this theory, we will explain the relations between the variables as presented below.

\section{o 1.3. Relation between the Independent Variables and Work Engagement}

Self-efficacy refers to one's "beliefs in one's capabilities to mobilize the motivation, cognitive resources, and courses of action needed to meet given situational demands" (Bandura, 1997). With that sense, those with high self-efficacy are more likely to undertake a proactive approach when faced with stressful situations and carry out a broader set of role responsibilities than those with low self-efficacy (Taştan, 2013). Perceived self-efficacy is a strong predictor of coping behavior (Bandura and Locke, 2003). With that sense, it was found that self-efficacy is positively related to contextual performance, task performance and general performance (Polatc1, 2014). Bakker et al. (2006) also found that female school principals with high personal resources which include resilience, self-efficacy and optimism scored highest in work engagement. Another study participated by clinicians specializing in Surgery Medicine demonstrated that personal resources (self-efficacy and resilience) have significant positive relationship with work engagement (Manche et al., 2014).

Based on the previous study results above, we propose the following hypothesis below:

H1: There is a positive relationship between Perceived Task Significance and Work Engagement of the employees. 
Luthans (2002) defined resilience as "positive psychological capacity to rebound, to bounce back from adversity, uncertainty, conflict, failure, or even positive change, progress and increased responsibility" (p.702). Resilience develops when one is "beset by problems and adversity, sustaining and bouncing back and even beyond to attain success" (Luthans, Youssef, and Avolio, 2007, p.3). Research studies in educational settings have shown that students with higher levels of resilience have stronger academic performance (As cited in Luthans and Jensen, 2012, p. 255). Polatc1 (2014) conducted a study in a sample of policemen and found that resilience is positively related to contextual performance, task performance and general performance. It has also been found that psychological capital has a strong positive relationship with job embeddedness and job performance (Sun, 2011). Based on the previous findings and literature implications, we have developed the second hypothesis as follows:

H2: There is a positive relationship between Perceived Person-Job Fit and Work Engagement of the employees.

Task significance, in literature, is used by researchers as "meaningfulness", "impact" as well as "task design" (Imhof, 2011, p. 8). Task significance reflects the degree to which a job influences the lives of others. Put differently, a job with a high level of task significance is one in which the job holder believes that the job has a demonstrable impact on others (Morgeson and Humphrey, 2006). Task significance is the extent to which the employee's work is important to others either within the organization or outside the organization (Duhn, 2013).Peccei (2013) demonstrated through the findings of meta-analyses that the strongest associations of work engagement antecedents, with corrected correlations above 0.50 , are particularly with task significance and self-efficacy. Shantz et al. (2014) obtained the results that employees who hold jobs that offer high levels of task significance are more highly engaged as well as committed (El-Asmar, 2013).Vybornova (2014) has found a significant relationship between task significance and job satisfaction. In relation with this, it has been found that task significance has a positive relationship with engagement (Guest, 2014). Depending on the previous literature, the following hypothesis is proposed:

H3: There is a positive relationship between perceived resilience and work engagement of the employees.

Trust-in-supervisor is defined as an employee's willingness to be vulnerable based on expectations his or her supervisor's intentions, words, or actions can be relied upon (Poon, 2013). Another definition in the literature is that "employee's faith in supervisor, and to the belief that ultimately the supervisor will act for the benefit of employees" (Ertürk, 2007 p.260). Trust in supervisor has been positively correlated with a subordinate's innovative behavior (Ruppel and Harrington, 2000). According to the findings, it has been found procedural fairness is positively related to trust in supervisor while trust in supervisor mediates the relationship between financial measures and job satisfaction (Chia, Lau and Tan 2014). Albrecht (2002) concluded that employees are more receptive to changes when they trust management. In line with this, subordinates with high trust level towards their supervisors are "more likely to accept the decisions of their supervisors more easily" (As cited in Arabac1, 2012). Employees' trust in direct supervisors and management is significantly and negatively associated with employees' antisocial work behaviors (Thau et al., 2007) and is related to task performance (Brower et al., 2009) as well as organizational commitment (Tan and Tan, 2000).Based on the previous findings and literature implications, we propose the second hypothesis as follows:

H4: There is a positive relationship between Perceived Self-Efficacy and Work Engagement of the employees. 
Person-Job fit is defined as the match between individual knowledge, skills, and abilities and demands of the job or the needs/desires of an individual and what is provided by the job (Uçanok, 2008). In other words, it refers to "the desires of the individual and the characteristics and the attributes of the job that may satisfy those desires. Individual's 'desires' include goals psychological needs, interests and values; while 'supply' has been described as general characteristics of occupation, pay and other job attributes" (As cited in Uçanok, 2008 p.25). As Jim Collins (2011) asserts in his book, "Good to Great", perhaps the most important things that managers did so as to bring about greatness to their good companies was to select the right person for the right job. The rest was very simply not to demotivate those proactive and resilient employees whose perception of self-efficacy and person-job fit is relatively high. In line with that, research showed that person-job fit is associated with job performance (June and Mahmood, 2011; Caldwell and O'Reilly, 1990), job satisfaction (Iqbal, Latif and Naseer, 2012), career success (Bretz and Judge, 1994). Edwards (1991) found that motivation, performance, job satisfaction, low job stress, and attendance as outcomes that are positively affected by person-job fit. Person-job fit has been found to mediate the relationship between job crafting (individual crafting and collaborative crafting) and job engagement (Chen, Yen and Tsai, 2014). The relationship between perceived person-job fit and intentions to accept a job offer was mediated by organizational attraction; and also, there was a direct relationship between perceived person-job fit and intentions to accept a job offer (Carless, 2005). There exists a very functional side of personjob fit that research has found a direct relationships as well as a mediating and moderating role of person-job fit in the relationship between perceived HR practices and employee outcomes (Boon et al., 2011). In the same vein, we have developed the hypothesis below:

H5: There is a positive relationship between Perceived Trust in Leader and Work Engagement of the employees.

\section{Methodology}

\subsection{The Research Aim and The Research Questions}

Considering the conceptual backround, this study aims to investigate the contribution of personal resources, task significance, trust in supervisor and person-job fit to work engagement and to explain the moderating role of work pressure on this contribution. As shown in Figure 6, the main research variables are organizational trust, work engagement and work pressure:

Considering the conceptual backround, this study aims to investigate the contribution of personal resources, task significance, trust in supervisor and person-job fit to work engagement and to explain the moderating role of work pressure on this contribution. As shown in Figure 1, the main research variables are organizational trust, work engagement and work pressure: 
Figure 1. The Proposed Research Model

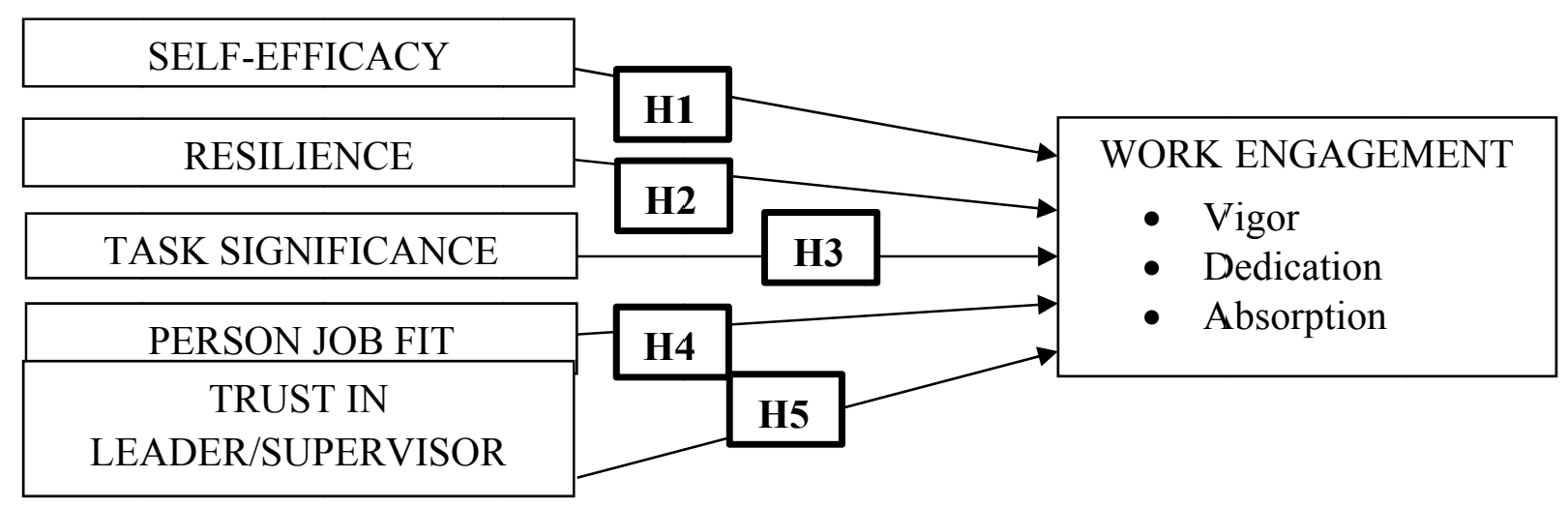

After having conducted all of the factor analysis and having revised the research model, we propose the hypotheses of the study below:

H1: There is a positive relationship between perceived self-efficacy and work engagement of the employees.

H2: There is a positive relationship between perceived resilience and work engagement of the employees.

H3: There is a positive relationship between perceived task significance and work engagement of the employees.

H4: There is a positive relationship between perceived person-job fit and work engagement of the employees.

H5: There is a positive relationship between perceived trust in leader and work engagement of the employees.

\subsection{Sample}

Sample of the study consists of white-collar, full-time, private sector employees of multinational companies and local firms in İstanbul studying MBA (Master of Business Administration) at the same time. There is not an age limitation for the sample. There is not researcher interference. Study setting is non-contrived, unit of analysis is individuals and time horizon of the study is cross-sectional. In total, 265 people filled the questionnaire.

\subsection{Procedure}

After having gathered the most appropriate scales of each variable and determining some of the items, the researchers examined the content validity of the questionnaire. For testing the content validity, the researchers asked 3 professors for the required modifications. Subsequently, due to the confirmation of the items, the questionnaires were distributed to the employees from different sectors directly while they were either around or in the classes of Istanbul University and Marmara University, during December and January months of the year 2015. On the cover of the questionnaire it was emphasized that respondents' confidentiality would be strictly kept by the researcher and the data would only be used for scientific research. Employees completed their questionnaires in their spare times and they returned their filled questionnaires to the researcher. 


\subsection{Instruments}

The internal consistency reliabilities for all the multi-item scales were assessed through Cronbach's Alpha. Cronbach's Alpha is a reliability coefficient, which shows how well the items in a set are positively correlated to one another (Sekaran, 2003). According to Nunnally and Brenstein (1994) if the value of the Cronbach's Alpha for a certain scale is 0.70 or above; that scale is deemed reliable.

\subsubsection{Measurement of Work Engagement}

Utrecht Work Engagement Scale (UWES) which was developed by Schaufeli, Salanova, González- Romá and Bakker (2002) was used to measure work engagement which has three dimensions; vigor, dedication and absorption. It consists of 17 items (for vigor 4 items, for dedication 9 items and for absorption 4 items). Usually values of Cronbach's alpha for each dimension scale range between .80 and .90 (Salanova, Grau, Llorens \& Schaufeli, 2001; Demerouti et al., 2001; Montgomery, Peeters, Schaufeli \& Den Ouden, 2003; Salanova, Bresó \& Schaufeli, 2003; Schaufeli, Taris \& Van Rhenen, 2003; Salanova, Carrero, Pinazo \& Schaufeli, 2003). Arabac1 (2012) also found the Cronbach's alpha values for each dimension of work engagement as 0,943 for dedication; 0,93 for absorption and 0,818 for vigor. Turgut (2011) has found Cronbach's alpha value for the whole scale containing 17 items as 0,89 ; and individually for each dimension as 0,81 for vigor; 0,87 for absorption; 0,86 for dedication. Chaudhary, Rangnekar and Barua (2012) has found the value of cronbach's alpha for the overall scale as 0.852. Bal (2008) has found the Cronbach Alpha values as $.9170, .8242$ and .7520 for the dedication, absorption and vigor factors respectively. Sample item for vigor is "I can continue working for very long periods at a time.", sample item for dedication is "I find the work that I do full of meaning and purpose." and sample item for absorption is "When I am working, I forget everything else around me.".

\subsubsection{Measurement of Self-Efficacy}

Self-efficacy is assessed with the ten-item Generalized Self-Efficacy Scale developed by Schwarzer and Jerusalem (1995). In the study conducted by Koçak (2013), cronbach's alpha has been found for the scale as 0,951. Schwarzer and Schroder (1997) have conducted a series of analysis in different cultures to determine reliability of the scale and found the Cronbach's alpha values as $0.84,0.81$ and 0.91 . In addition to that, Rimm and Jerusalem (1999) has reported that the internal consistency of the Self-Efficacy scale has been measured as 0.87 . In a study conducted in Turkey by Erci (2005), Cronbach's Alpha value has been found as 0.89. Finally, Tösten and Özgan (2014) has found the internal consistency of the scale as 0.80 . In the current study, Cronbach's Alpha value has been found as 0.934 .

The scale items are rated on a 6-point scale ranging from (1) "totally disagree" to (6) "totally agree". The Turkish adaptation of the scale was made by Taştan (2010). The researcher and the thesis advisor made minor changes on this Turkish translation before including this scale in the final questionnaire. No reverse items were used in this measure. Two sample items are "I can always manage to solve difficult problems if I try hard enough" and "When I am confronted with a problem, I can usually find several solutions." 


\subsubsection{Measurement of Resilience}

We have benefited from Psychological Capital Scale which consists 24 items. Resilience scale is taken out of that particular scale which is composed of 6 items. Turkish translation of the scale was formed by the help of previous research (Polatç1, 2011; Çınar, 2011) through evaluation of each item and selecting the appropriate one. No reverse item is used.

In a pilot study conducted in Turkey by Polatçı (2011), the researcher has found Cronbach's Alpha value in an acceptable range. Polatçı (2011) has also found the Cronbach's alpha value as 0.85 as a result of the study. In addition to that, Tösten and Özgan (2014) has found the internal consistency of the scale as 0.76. Wagnild and Young (1993) has found the internal consistency of the scale as 0.91. In this current study, Cronbach's Alpha value of the scale has been found as 0.805 .

\subsubsection{Measurement of Task Significance}

Task Significance was measured by a scale formed by the researcher through evaluating two scales developed by Morgeson and Humphrey(2006) ve Rodopman (1999). No reverse items is used. A sample item of the 4-item scale is "The job I perform is helpful and important for the society." The scale previously demonstrated very good reliability, $\alpha=.87$ (Morgeson and Humphrey, 2006). The reliability coefficient for this scale in another study was measured as $\alpha=.86$ (El-Asmar, 2013). Rodopman (1999) has found the Cronbach's Alpha value as 0.86 . In the current study, the internal consistency of the scale has been found as 0.926 .

\subsubsection{Measurement of Person-Job Fit}

Person-job fit is measured by the self-report test developed by Brkich, Jeffs and Carless (2002). The test is translated into Turkish by the Uçanok (2008) and each item is examined to match the meaning in the original test by Uçanok (2008). $1^{\text {st }}, 2^{\text {nd }} 4^{\text {th }}$ and $8^{\text {th }}$ questions of the 9item scale are reverse questions.

In a study conducted in Turkey, Uçanok (2008) has found the Cronbach's alpha of the turkish version scale as 0.90 ; The misfit factor (1., 2., 4. and 8. questions) implies that the job does not meet one's expectations $(\alpha=0.8428)$, and the fit factor (3., 5., 6., 7. and 9. questions) $(\alpha=0.8666)$ implies that there is congruity and satisfaction between the person and the job. In the current study Cronbach's Alpha value for the overall scale has been found as 0.868 ; and for the two factors "fit" and "misfit" 0.847 (5-items factor) and 0.801 (4-items factor) respectively. Additionally, since we have found the percentage explained by the "fit" factor as $49,605 \%$ which is greater than $30 \%$, we will take into consideration only this dimension of the scale as the representative in correlation and regression analysis.

The test is rated on a scale ranging from 'definetely agree' (1) to 'definetely disagree' (6). Two sample questions second of which is reverse are as follows; "My current job motivates me" and "I think that another job is more convenient for me."

\subsubsection{Measurement of Trust in Supervisor}

Trust in Supervisor was measured by İslamoğlu, Birsel and Börü's Trust Scale (2007) which consists of 10 items (for trust in supervisor 10 items). This scale was chose for the study because of its appropriateness to Turkish culture. Sample items for trust in 
supervisor are "My supervisor shares her/his knowledge", "My Supervisor is honest and fair" and "My Supervisor is such a team leader."

In a study conducted in Turkey, the internal consistency of the scale was found as .961 (Arabac1, 2012). Chughtai (2010) has found the internal consistency of the scale as 0.96 . The Cronbach's Alpha values in the current study has been found as 0.955 .

\subsubsection{Items Related To Demographics}

Survey has 9 questions about demographic variables 8 of them are multiple-choice questions while only one is open-ended. The open ended question is age. Other demographics are gender, marital status, education level, total work experience, company experience, title, type of company they work at and the department they perform their tasks in.

\section{Findings}

Statistical Package for the Social Sciences 20.0 for Windows (SPSS) was used to analyze the data collected through questionnaires. The raw data was entered to SPSS and the following statistical analyses were done after checking for normal distribution on item basis and eliminating any outliers: factor analysis, reliability analysis, hypothesis tests (correlation, simple regression and multiple regression analysis).

Three factors came out at the end of the factor analysis of work engagement while the results KMO yielded a value of ,918 and the Bartlettes test of sphericity yielded a significant result with a $\mathrm{p}=.000$. Thus, it was concluded that the data is appropriate for the factor analysis to be performed for this scale. Second item of the scale was omitted and the rest was entered into factor analysis and it was found that the variable consisted of three dimensions; namely dedication, absorption and vigor. The rest of the 17 items loaded under 3 factors which explained $65,326 \%$ of the total variance.

Reliability analyses for each dimension of work engagement were performed. All of the factors showed high internal consistencies, which were 0,895 for absorption, 0,880 for dedication, and 0,751 for vigor. The percentage variance explained values are 46,532 for absorption, 10,910 for dedication and 7,884 for vigor dimension.

Person-Job Fit has been divided into two factors as a result of the factor analysis. Since the percentage of variance explained by the first dimension is $49,605 \%$ and highly greater than $30.0 \%$. Thus, we have named the entire variable of 5-items as person-job fit to represent the mentioned variable. Other four independent variables of the study; self-efficacy, resilience, task significance, trust in supervsior have been found as being composed of single factors. 
Table 1: Means and Reliabilities of the Variables Examined in the Study

\begin{tabular}{lccc}
\hline \multicolumn{1}{c}{ VARIABLEs } & Mean (M) & Std. Deviation (SD) & Cronbach Alpha $(\boldsymbol{\alpha})$ \\
\hline Work Engagement & 3,99 & 14,022 & 0,920 \\
& 3,92 & 7,329 & 0,895 \\
Absorption & 4,01 & 6,255 & 0,880 \\
Dedication & 4,12 & 2,845 & 0,751 \\
Vigor & 4,52 & 8,267 & 0,934 \\
Self-Efficacy & 4,47 & 4,508 & 0,886 \\
Resilience & 4,29 & 3,998 & 0,826 \\
Task Significance & 3,85 & 9,286 & 0,868 \\
Person-Job Fit & 3,83 & 29,679 & 0,847 \\
Fit & 3,86 & 5,031 & 0,801 \\
Misfit & 3,96 & 12,559 & 0,955 \\
Trust in Supervsior & & & \\
\end{tabular}

\subsection{Findings Related to the Hypotheses}

Table 2. Correlation Analysis of all Variables of the Study

\begin{tabular}{lccccccccc}
\hline VARIABLES & 1-WE & 2-A & 3-D & 4-V & 5-SE & 6-R & 7-TS & 8-PJF & 9-TiS \\
1.WorkEngagement & 1 & & & & & & & & \\
2.Absorption &, $892^{* *}$ & 1 & & & & & & & \\
3.Dedication &, $730^{* *}$ &, $535^{* *}$ & 1 & & & & & & \\
4.Vigor &, $865^{* *}$ &, $585^{* *}$ &, $556^{* *}$ & 1 & & & & & \\
5.Self-Efficacy &, $551^{* *}$ &, $430^{* *}$ &, $577^{* *}$ &, $470^{* *}$ & 1 & & & & \\
6.Resilience &, $537^{* *}$ &, $420^{* *}$ &, $604^{* *}$ &, $438^{* *}$ &, $738^{* *}$ & 1 & & & \\
7.TaskSignificance &, $591^{* *}$ &, $473^{* *}$ &, $414^{* *}$ &, $582^{* *}$ &, $502^{* *}$ &, $513^{* *}$ & 1 & & \\
8.Person-JobFit &, $431^{* *}$ &, $241^{* *}$ &, $277^{* *}$ &, $558^{* *}$ &, $213^{* *}$ &, $292^{* *}$ &, $502^{* *}$ & 1 & \\
9.TrustinSupervisor &, $336^{* *}$ &, $223^{* *}$ &, $245^{* *}$ &, $381^{* *}$ &, $130^{* *}$ &, $174^{* *}$ &, $265^{* *}$ &, $241^{* *}$ & 1 \\
\hline
\end{tabular}

**.Correlationissignificantatthe 0.01 level(2-tailed).

*.Correlationissignificantatthe0.05level(2-tailed).

With the purpose of testing the hypotheses, we have conducted correlation analysis and have obtained results as shown above in the Table 15. As we look at the first hypothesis, selfefficacy has strongly significant positive relationship with work engagement $(r=0,551 ; \mathrm{p}<$ $0,01)$ and its sub-dimensions; absorption $(\mathrm{r}=0,430 ; \mathrm{p}<0,01)$, dedication $(\mathrm{r}=0,577 ; \mathrm{p}<0,01)$ and vigor $(r=0,470 ; p<0,01)$ with a significance $p$ value of lower than 0,01 . When it comes to the second hypothesis, resilience has also strongly significant positive relationship with work engagement $(\mathrm{r}=0,537 ; \mathrm{p}<0,01)$ and its sub-dimensions; absorption $(\mathrm{r}=0,420 ; \mathrm{p}<$ $0,01)$, dedication $(r=0,604 ; p<0,01)$ and vigor $(r=0,438 ; p<0,01)$ with a significance $p$ value of lower than 0,01 . As to the third hypothesis, task significance has strongly significant positive relationship with work engagement $(\mathrm{r}=0,591 ; \mathrm{p}<0,01)$ and its sub-dimensions; absorption $(r=0,473 ; p<0,01)$, dedication $(r=0,414 ; p<0,01)$ and vigor $(r=0,582 ; p<$ 0,01 ) with a significance $p$ value of lower than 0,01 as well. As for the fourth hypothesis, person-job fit has strongly significant positive relationship with work engagement $(\mathrm{r}=0,431$; $\mathrm{p}<0,01)$ and its sub-dimensions; absorption $(\mathrm{r}=0,241 ; \mathrm{p}<0,01)$, dedication $(\mathrm{r}=0,277 ; \mathrm{p}<$ $0,01)$ and vigor $(r=0,558 ; p<0,01)$ with a significance $p$ value of lower than 0,01 . Finally, the fifth hypothesis, trust in supervsior fit has strongly significant positive relationship with 
work engagement $(\mathrm{r}=0,336 ; \mathrm{p}<0,01)$ and its sub-dimensions; absorption $(\mathrm{r}=0,223 ; \mathrm{p}<$ $0,01)$, dedication $(r=0,245 ; \mathrm{p}<0,01)$ and vigor $(\mathrm{r}=0,381 ; \mathrm{p}<0,01)$ with a significance $\mathrm{p}$ value of lower than 0,01 as well.

In addition to all of the findings, if we observe the correlation values between the independent variables, we see that they have positive significant relationship with one another.

Hypothesis 1; there is a positive relationship between perceived self-efficacy and work engagement of the employees, has been supported.

Hypothesis 2; there is a positive relationship between perceived resilience and work engagement of the employees, has been supported.

Hypothesis 3; there is a positive relationship between perceived task significance and work engagement of the employees, has been supported.

Hypothesis 4; there is a positive relationship between perceived person-job fit and work engagement of the employees, has been supported.

Hypothesis 5; there is a positive relationship between perceived trust in supervisor and work engagement of the employees, has been supported.

Table 3. Simple Regression Analysis Results For Independent Variables on Work Engagement

\begin{tabular}{|c|c|c|c|}
\hline IndependentVariable & & ntVariable:V & ient-Total \\
\hline Self-Efficacy & $\begin{array}{l}\text { Beta( }(\boldsymbol{\beta}) \\
0,551\end{array}$ & $\begin{array}{l}\text { tvalue } \\
10,721\end{array}$ & $\begin{array}{l}\text { pvalue } \\
0,000\end{array}$ \\
\hline $\mathrm{R}=0,551$ & $\mathrm{R}^{2}=, 304$ & $\mathrm{~F}=114,936$ & $\mathrm{p}=0,000$ \\
\hline Resilience & $\begin{array}{l}\operatorname{Beta}(\boldsymbol{\beta}) \\
0,537\end{array}$ & $\begin{array}{l}\text { tvalue } \\
10,334\end{array}$ & $\begin{array}{l}\text { pvalue } \\
0,000\end{array}$ \\
\hline $\mathrm{R}=0,537$ & $\mathrm{R}^{2}=, 289$ & $F=106,785$ & $\mathrm{p}=0,000$ \\
\hline TaskSignificance & $\begin{array}{l}\text { Beta( }(\boldsymbol{\beta}) \\
0,591\end{array}$ & $\begin{array}{l}\text { tvalue } \\
11,877\end{array}$ & $\begin{array}{l}\text { pvalue } \\
0,000\end{array}$ \\
\hline $\mathrm{R}=0,591$ & $\mathrm{R}^{2}=, 349$ & $\mathrm{~F}=141,056$ & $\mathrm{p}=0,000$ \\
\hline Person-JobFit & $\begin{array}{l}\operatorname{Beta}(\boldsymbol{\beta}) \\
0,431\end{array}$ & $\begin{array}{l}\text { tvalue } \\
7,748\end{array}$ & $\begin{array}{l}\text { pvalue } \\
0,000\end{array}$ \\
\hline $\mathrm{R}=0,431$ & $\mathrm{R}^{2}=, 186$ & $\mathrm{~F}=60,027$ & $\mathrm{p}=0,000$ \\
\hline TrustinSupervisor & $\begin{array}{l}\operatorname{Beta}(\boldsymbol{\beta}) \\
0,336\end{array}$ & $\begin{array}{l}\text { tvalue } \\
5,786\end{array}$ & $\begin{array}{l}\text { pvalue } \\
0,000\end{array}$ \\
\hline $\mathrm{R}=0,336$ & $\mathrm{R}^{2}=, 113$ & $F=33,476$ & $\mathrm{p}=0,000$ \\
\hline
\end{tabular}

Table 4. Multiple Regression Analysis Results For All of the Independent Variables on Work Engagement 
DependentVariable:

$\begin{array}{lllc} & \operatorname{Beta}(\boldsymbol{\beta}) & \text { tvalue } & \text { pvalue } \\ \text { Independent Variables } & 0,702 & & 0,000 \\ \text { Self-Efficacy } & 0,350 & 6,850 & 0,000 \\ \text { TaskSignificance } & 0,282 & 4,826 & 0,000 \\ \text { Person-JobFit } & 0,173 & 3,360 & 0,001 \\ \text { TrustInSupervisor } & 0,174 & 3,765 & 0,000 \\ \text { R=0,702 } & \mathrm{R}^{2}=, 493 & \mathrm{~F}=63,174 & \mathrm{p}=0,000\end{array}$

We have also examined whether such hypothesis as all of the independent variables together have a positive relationship with work engagement and explains considerable amount of the dependent variable of the current study, work engagement. So as to test such claim, we have conducted multiple regression analysis and obtained a statistically significant positive relationship between all the independent variables and work engagement. Furthermore, the percentage that these independent variables explain the variance of work engagement is $48,8 \%$ which is a considerable amount to predict the dependent variable based on these independent variables.

Simple regression analysis was conducted to examine the contribution of selfefficacy to work engagement. The results showed that self-efficacy has positive impact on work engagement representing a moderate regression $(\beta=0,551 ; p=0,000)$ $\begin{array}{llll}\text { and that } & \text { self-efficacy } & 30,4 \%\end{array}$ $\left(\mathrm{R}^{2}=, 304\right)$ of the variance in work engagement.

Simple regression analysis was conducted to examine the contribution of resilience to work engagement. The results showed that resilience has positive impact on work engagement at moderate level $(\beta=0,537 ; \mathrm{p}=0,000)$ and that resilience explains $28,9 \%\left(\mathrm{R}^{2}=, 289\right)$ of the variance in work engagement.

Simple regression analysis was conducted to examine the contribution of task significance to work engagement. The results showed that task significance has positive impact on work engagement representing a moderate regression $(\beta=0,591 ; \mathrm{p}$ $=0,000)$ and that task significance explains $34,9 \%\left(\mathrm{R}^{2}=, 349\right)$ of the variance in work engagement.

Simple regression analysis was conducted to examine the contribution of personjob fit to work engagement. The results showed that person-job fit has positive impact on work engagement at a weak level of regression $(\beta=0,431 ; p=0,000)$ and that person-job fit explains $18,6 \%\left(\mathrm{R}^{2}=, 186\right)$ of the variance in work engagement.

Simple regression analysis was conducted to examine the contribution of trust in supervisor to work engagement. The results showed that trust in supervisor has positive impact on work engagement representing a weak level of regression $(\beta=$ 
$0,336 ; \mathrm{p}=0,000)$ and that trust in supervisor explains $11,3 \%\left(\mathrm{R}^{2}=, 113\right)$ of the variance in work engagement.

\subsection{Comparative Tests Related with the Demographics}

To examine the possible significant differences between gender groups and the employees working in multinational companies and local firms in terms of the variables of the study, independent samples t-tests were conducted.

When the grouping variable is gender which was measured on a nominal scale and the dependent variable is work engagement which was measured with an interval scale, there was not a significant difference, since the $p$ value of 0,367 in the Levene's test for equality of variances tells us that the results of the t-test analysis between female and male employees in terms of work engagement variable is not significant. In other words, there is no difference between the groups of gender in terms of work engagement.

As for the grouping variable is company type which was measured on a nominal scale and the dependent variable is work engagement which was measured with an interval scale, there was not a significant difference, since the $p$ value of 0,506 in the Levene's test for equality of variances tells us that the results of the t-test analysis between employees working in local and multinational companies in terms of work engagement variable is not significant. In other words, there is no difference between the groups of company type in terms of work engagement.

After we have conducted one-way ANOVA test, we firstly checked the p significance value in the test of homogeneity of variances table given by SPSS where the $p$ value was found 0,212 which is greater than 0,05 . Thus, we can move on to the ANOVA table in order to interpret the results where we have obtained another $p$ value of 0,05 which tells us there are significantly different groups from one another among these three $(F=5,406 ; p=0,05<0,50)$. Hence, we move on to the Tukey and Sheffe tables where we see that there are only one significant difference among the position levels; the mean of first line and the mean of the upper level are significantly different from one another $\left(\operatorname{Mean}_{\text {Upper Level }}=3,7529>\right.$ Mean $\left._{\text {First Line }}=4,4036 ; p=0,007<0,05\right)$.

\section{Conclusion and Discussion}

In this study, the contribution of self-efficacy, resilience, task significance, personjob fit and trust in supervisor to work engagement was examined. The conceptual model of the current study was developed relying upon the Job Demand-Resources Theory. Specifically, the contribution of self-efficacy, resilience and task person-job fit variables onto work engagement can be premised on this theory. The following sections include the interpretation and the evaluation of the research findings along with an approach of comparing and contrasting the results of the current study with the results of the previous studies.

The sample of the research was chosen as full and pat-time employees from different sectors continuing their master education in Istanbul and Marmara Universities and 265 people were participated in the study. In the literature, there are many researchers who investigated self-efficacy, resilience, task significance, person-job fit and trust in supervisor as well as work engagement. 
The data collected from 265 employees were analyzed through SPSS 20.0 and the results are summarized below with some comparisons between the previous studies in the literature. The statistical analysis of the main data was started with the factor and reliability analysis, in order to point out the applicability of the scales used for the research. The factor analysis results revealed that, work engagement variable consisted of three and person-job fit is composed of two dimensions while other variables of the study appeared to be formed by single dimension. Work engagement dimensions are found to be absorption, dedication and vigor as many researchers termed them previously (Schaufeli and Bakker, 2003; Dalay, 2007; Bal; 2008; Arabac1, 2012; Koçak, 2013). In the factor analysis, one item of the scale was extracted because of having close factor loading values in two different dimensions and the factor analysis has been conducted again. The results revealed that the items constituting three dimensions (absorption, dedication and vigor) explained 65,326\% of the total variance in work engagement. The reliability of the scale for the dimensions were 0,895 for absorption; 0,880 for dedication and 0,751 for vigor. The cronbach's alpha values for all the three dimensions were found to be over 0,80 in previous research (Erim et al. 2009; Arabac1, 2012).

After having conducted factor analysis on each independent variable as well, we have termed the person-job fit variable, which has been divided into two sub-dimensions, as fit and misfit respectively. Uçanok (2008) has also termed the same sub-dimensions as "fit" and "misfit" in previous research. Since the first dimension of the person-job fit, "fit" explains a considerable amount of the variance in person-job fit variable with a percentage of 49,605, we have taken into consideration only this particular dimension in further analysis to represent the whole variable, person-job fit.

Before regression analysis, correlation analysis was carried out with all the dimensions of the research variables, in order to test whether there was multicollinearity problem for the study or not. The findings revealed that self-efficacy was correlated to work engagement dimensions at the moderate level, supporting the findings of Bal (2008), Chaudhary (2012), Pati and Kumar (2010) and Collins (2009) who denoted the relationship between perceived self-efficacy and work engagement of the employees. Note that, there was no multicollinearity problem. After having seen this positive result, followingly the regression analyses were applied.

Supporting the findings of Chaudhary (2011) and Bae (2009), Peterson (2002) while testing the first hypothesis of the research, it was investigated that the level of self-efficacy had a positive contribution to work engagement. To test this relationship, firstly simple regression analysis was conducted with the total self-efficacy and total work engagement which suggested a statistically significant positive contribution, in accordance with the previous studies. The contribution of self-efficacy as a personal resource as a predictor of work engagement using a sample comprising 274 teachers was also examined by Prieto (2009). The results in many previous studies revealed that self-efficacy significantly predicted work engagement measuring via the UWES (Schaufeli and Bakker, 2003; Dalay, 2007; Bal; 2008; Arabac1, 2012; Koçak, 2013).

As for the other independent variables, we have also applied simple regression analysis for each and obtained results as in previous studies. Resilience was found to have positive weak level of correlation with two dimensions of work engagement, absorption and vigor. When it comes to dedication dimension, the correlation between resilience and dedication was moderate in the current study supporting the previous findings by Koçak (2013) and Herbert 
(2011). Task Significance was also found to be weakly correlated with absorption and dedication while having a moderate relationship with vigor dimension of work engagement. Koçak's (2013) findings are in line with the results of the current study. The influence of task significance was also supported by Shantz et. al. (2013). Person-job fit variable was found to have positive have weak correlation with absorption and dedication while having moderate correlation with vigor supporting the findings by Schönherr (2011) and Shuck (2011). Finally for trust in supervisor had also positive significant correlations with dimensions of work engagement supporting the findings by Arabacı (2012) and Bartelme (2012).

As to the t-test results which showed that there is not a significant difference between groups of local organizations and multinational organizations, it might be because participants of the study have the same cultural assumptions and behavioral habits, even if they are working in different sort of organizations, local and multinational. If such analysis was conducted in different cultures encompassing different countries, the difference between local organizations and multinational organizations could be significant.

As the results of the study indicate; self-efficacy, resilience, task significance, personjob fit and trust in supervisor variables have positive significant relationship with work engagement variable at each. Other important finding of the research is that, when all of the independent variables except resilience are taken into account, they have also positive significant contribution to work engagement. More engaged employees with high perceived self-efficacy, task resilience, person-job fit and trust in supervisor provide their organizations a competitive advantage in this rapidly changing, challenging business world in many ways. People who are engaged in their jobs tend to work harder and be more productive than other employees. These employees are also more likely to meet the needs of their customers and to improve customer loyalty which in return increases sales and profits. To sum up, the top management of the companies should recognize the importance of work engagement and should take some actions to increase the antecedents especially like perceived self-efficacy, resilience, task significance, person-job fit and ultimately trust in supervisor by selecting the right people for the right job. Organizations which manage to increase and keep these variables at high level will have more engaged and committed employees while meeting financial and other critical business goals in the long run.

\section{Limitations of the Study}

First limitation of this study is its generalizability, due to the geographic boundaries of the data collected for the study. The inferences drawn from such a sample in Istanbul city may not be fully generalizable to whole country or the employees from other countries in different cultures.

Another limitation is about the content of the measurement items. The trust in supervisor scale was developed for Turkish culture by Turkish academicians; but work engagement and other scales were developed by scholars from other cultures. Thus, they may not be as suitable as the trust in supervisor scale for the sample of the research.

Finally, because of the research domain concerning work engagement, this study did not address other institutional variables, such as firm ownership, workplace cultures, working hours, organizational sizes, organizational structure and profitability. 


\section{Suggestions for Further Research}

In order to make a better explanation of the relationship between the research variables, a broader geographic region can be chosen with a higher number of participants as the sample group. This would enable the research findings to be more valid and accredited. Moreover, to increase the credibility of the study, like the scale used measuring trust in supervisor in this research which provides a well-advised design of measurement of trust in supervisor; also for the other variables, the new scales developed for Turkish culture should be used.

Another suggestion for other researchers is the application of another questionnaire to supervisors about their subordinates. In this way, in addition to the perceptions of the relatively lower level employees, also the opinions of their supervisors and managers can be acquainted.

\section{REFERENCES}

- Albrecht, S. L. (2002). Perception of integrity, competence and trust in senior management as determinants of cynicism towards change.Public Administration and Management, 7, 320-343.

- Arabaci, T. (2012). The Role of Organizational Trust on Work Engagement With The Moderating Effect Of Work Pressure, Marmara University, Social Sciences Institute, Management and Organization, Master Thesis.

- Bae, M. (2009). "Effect Of Group Music Therapy on Student Music Therapists Anxiety, Mood, Job Engagement And Self-Efficacy", Unpublished Doctorate Dissertation, University of Kansas, Social Sciences Institute, Deparment of Psychology.

- Bakker A.B., and Gieveld J. H., Van Rijswijk K. (2006). A study on burnout, work engagement and performance.Right Management Consultants.

- Bakker, A. B. (2011). An evidence-based model of work engagement.Current Directions in Psychological Science, 20, 265-269.

- Bakker, A. B. (2011). An evidence-based mosdel of work engagement. Current Directions in Psychological Science, 20(4), 265-269.

- Bakker, A. B. and W. B. Schaufeli. (2008). Positive organizational behavior: Engaged employees in flourishing organizations. Journal of Organizational Behavior 29, 147-154.

- Bakker, A., and Demerouti, E. (2008).Towards a model of work engagement. Career Development International, 13(1), 209-223.

- Bakker, A.B., Demerouti, E., and Schaufeli, W.B. (2003). Dual processes at work in a call centre: An application of the Job Demands a Resources model. European Journal of Work and Organizational Psychology. 12, 393-417.

- Bakker, A.B., Schaufeli, W.B., Leiter, M.P. and Taris, T.W. (2008). Work engagement: An emerging concept in occupational health psychology. Work and Stress, 22(3), 187-200.

- Bal, E. (2008). Self-Efficacy, Contextual Factors And Well-Being: The Impact Of Work Engagement, Marmara University, Unpublished Doctoral Dissertation.

- Bandura, A. (1997). Insight.Self-efficacy.Harvard Mental Health Letter. 13(9), 46. 
- Bandura, A. Locke, E. A. (2003). Negative Self-Efficacy and Goal Effects Revisited. Journal of Applied Psychology. 88(1), 87-99.

- Bartelme, T. F. (2012). An Exploration Of The Relationship Between Employee Engagement And Trust. Unpublished Doctoral Dissertation, Capella University, Social and Behavioral Sciences, Deparment of Business Administration.

- Boon, C. Hartog, D. N. Boselie, P. and Paauwe, J. (2011). The relationship between perceptions of HR practices and employee outcomes: examining the role of person-organisation and person-job fit. The International Journal of Human Resource Management, (22) 1, p.138-162.

- Bretz, R.D. and Judge, T.A. (1994). Person-organization fit and the theory of work adjustment: implications for satisfaction, tenure, and career success. Journal of Vocational Behavior, 44, 32-54.

- Brower, H. H. Lester, S. W. Korsgaard, M. A. and Dineen, B. R. (2009). A Closer Look at Trust between Managers and Subordinates: Understanding the Effects of both Trusting and Being Trusted on Subordinate Outcomes. Journal of Management, 35, 327-347.

- Caldwell, D. F. and O'Reilly, C. A. (1990). Measuring Person-Job Fit With a Profile-Comparison Process. Journal of Applied Psychology, 75(6), 648-657.

- Carless, S. A. (2005). Person-job fit versus person-organization fit as predictors of organizational attraction and job acceptance intentions: A longitudinal study. Journal of Occupational and Organizational Psychology, 78, 411-429.

- Chen, C. Yen, C. and Tsai, F. C. (2014). Job crafting and job engagement: The mediating role of person-job fit. International Journal of Hospitality Management 37, 21- 28.

- Chughtai, A. A. 2010, Fostering Work Engagement through State and Trait Trust: Evidence from Irish University Research Centres, Unpublished Doctorate Dissertation, Dublin University, Social Sciences Institute, Deparment of Administration.

- Collins, J. (2001). Good to Great, William Collins, United States.

- Collins, K. K. (2009). "Examining a strengths-based approach to employee engagement and the mediating effects of strengths self-efficacy", Unpublished Doctorate Dissertation, Aliiant International University, Social Sciences Institute, Deparment of Psychology.

- Criscitelli, T. (2014). "The Job Demands-Resource Model and Work Engagement For Perioperative Nurse Managers", Unpublished Doctorate Dissertation, Walden University, Social Sciences Institute, Deparment of Psychology.

- Cruz, J. G. Cabrera, R. V. and Llusar, J. C. B. (2014). La generación de confianza en un contexto de intercambio social: la relación supervisor supervisado. Revista europea de dirección y economía de la empresa, (23) 2, p. $61-71$

- Dalay, G. (2007). The Relationship Between The Variables Of Organizational Trust, Job Engagement, Organizational Commitment And Job Involvement. Unpublished Master Thesis, Marmara University, Social Sciences Institute, Deparment of Organizational Behavior. 
- Demerouti, E., and Bakker, A. B. (2011). The job demands-resources model: Challenges for future research. SA Journal of Industrial Psychology, 37 (2), 974-983.

- Demerouti, E., Bakker, A.B., Janssen, P.P.M. and Schaufeli, W.B. (2001). Burnout and engagement at work as a function of demands and control. Scandinavian Journal of Work, Environment \& Health, 27, 279-286.

- Duhn, S. T. (2013). Examining Correlates of Part-time Faculty Affective Commitment and Job Satisfaction. Unpublished Doctorate Dissertation, Northcentral University, Social Sciences Institute, Deparment of Business Administration.

- Edwards, J.R. (1991). Person-job fit: a conceptual integration, literature review, and methodological critique. Cooper, C.L., Robertson, I.T. tarafindan alıntılanmış: (Eds),International Review of Industrial and Organizational Psychology, John Wiley and Sons, Chichester, pp.283-358.

- Erci B. (2005). Genel Algılanan Öz-Yeterlilik Ölçeğinin Türkçe versiyonu, 3.Uluslararas1-10. Ulusal Hemşirelik Kongresi Özet Kitabı, İzmir.

- Erim, F.N.A., and Artan, İ.E. (2009). Individual response to organizational change: Creating facade of conformity its antecedents and effects on participating in decision making, work engagement, job involvement and intent to quit. Marmara University, Social Sciences Institute, Organizational Behavior Department, Unpublished doctoral dissertation.

- Ertürk, A. (2007). Increasing Organizational Citizenship Behaviors Of Turkish Academicians Mediating Role Of Trust İn Supervisor On The Relationship Between Organizational Justice And Citizenship Behaviors. Journal Of Managerial Psychology, 22(3), 257-270.

- Guest, D. (2014). Employee engagement: a sceptical analysis, Journal of Organizational Effectiveness:People and Performance, 1(2), 141 - 156.

- Herbert, M. (2011), “An Exploration Of The Relationships Between Psychological Capital (Hope, Optimism, Self-Efficacy, Resilience), Occupational Stress, Burnout And Employee Engagement", Unpublished Master Thesis, The University Of Stellenbosch, Social Sciences Institute, Deparment of Psychology.

- Hobfoll, S. E. (2002). Social and psychological resources and adaptation.Review of General Psychology. 6, 307-324.

- Hobfoll, S. E., and Shirom, A. (2001).Conservation of Resources Theory.in R. Golembiewski (Ed.), Handbook of Organizational Behavior. New York, NY: Dekker. pp. 57-80.

- Hornung, S. Weigl, M. Petru, R. Glaser, J. and Angerer, P. 2011. Work Engagement And Accumulation Of Task, Social, And Personal Resources: A Three-Wave Study. Academy of Management Annual Meeting Proceedings.

- Imhof, A. (2011). Messung der Arbeitszufriedenheit: Teststatische und konzeptionelle Untersuchungeines Fragebogens für den Langzeit pflege bereich (The Measurement of Job satisfaction: Test statistics and conceptually investigating questionnaires for the long-term care area). Unpublished Master Dissertation, Zürcher Hochschule, Psychology Department.

- Iqbal, M. T. Latif, W. and Naseer, W. (2012).The Impact of Person Job Fit on Job Satisfaction and its Subsequent Impact on Employees Performance. Mediterranean Journal of Social Sciences, 3 (2), 523-530. 
- İslamoğlu, G., Birsel, M., Börü, D. (2007). Kurum içinde güven. İnkılap Kitapevi, İstanbul.

- Jones, F., and Fletcher, B. (1996).Job control and health.in M. J. Schabracq, J. A. M. Winnubst,and C. L. Cooper (Ed.), Handbook of work and health psychology.Chichester, England: Wiley. 33-50.

- Jonge, J. D. and Le Blanc, P. M., Peeters, M. C., and Noordam, H. (2008). Emotional job demands and the role of matching job resources: A crosssectional survey study among health care workers. International Journal of Nursing Studies, 45, 1460-1469.

- June, S. and Mahmood, R. (2011). The Relationship between Person-job Fit and Job Performance: A Study among the Employees of the Service Sector SMEs in Malaysia. International Journal of Business, Humanities and Technology 1(2), 95-105.

- Kahn, W.A. (1990). Psychological conditions of personal engagement and disengagement at work. Academy of Management Journal, 33, 692-724.

- Kim, H.J., Shin, K.H. and Swanger, N. (2009). Burnout and engagement: A comparative analysis using the Big Five personality dimensions. International Journal of Hospitality Management, 28, 96-104.

- Kim, W. Kolb, J. A. and Kim, T. (2013). The Relationship Between Work Engagement and Performance: A Review of Empirical Literature and a Proposed Research Agenda. Human Resource Development Review, 12(3), 248 $-276$.

- Koçak, Ö.E. (2013). The Moderating Effect Of Self-Efficacy On The Relationship Between Job Resources And Work Engagement, Unpublished Master Dissertation, Marmara University, Social Sciences Institute, Department of Organizational Behavior .

- Luthans F, Youssef CM, and Avolio B.J. (2007).Psychological capital. Oxford: Oxford University Press.

- Luthans, K. W. and Jensen, S. M. (2012).The Impact of Business School Students' Psychological Capital on Academic Performance. Journal Of Education For Business, 87, 253-259.

- Macey, W. H., and Schneider, B. (2008).The meaning of employee engagement. Industrial and Organizational Psychology, 1(1), 3-30.

- Manche, S. Vitzthum, K. Klapp, B. F. and Danzer, G. (2014). Surgeons' work engagement: Influencing factors and relations to job and life satisfaction. The Surgeon 12, 181-190.

- Montgomery, A., Peeters, M.C.W., Schaufeli, W.B. and Den Ouden, M. (2003). Work-home interference among newspaper managers: Its relationship with Burnout and engagement. Anxiety, Stress \& Coping, 16, 195-211.

- Morgeson, F. P., and S. E. Humphrey. (2006). The Work Design Questionnaire (WDQ): Developing and validating a comprehensive measure for assessing job design and the nature of work. Journal of Applied Psychology 91, 1321-39.

- Park, Y. K. Song, J. H. and Yoon, S. W. Kim, J. (2013). Learning organization and innovative behavior The mediating effect of work engagement. European Journal of Training and Development, 38 (1/2), 75-94. 
- Pati, S. P. Kumar, P. (2010). Employee Engagement: Role of Self-efficacy, Organizational Support and Supervisor Support. The Indian Journal of Industrial Relations, 46(1).

- Peccei, R. (2013). "Engagement at work: an evidence-based review", in Bach, S. and Edwards, M. (Eds), Managing Human Resources, 5th ed., Wiley, Chichester, 336-363.

- Peterson, F. L. S. J. (2002). "Employee engagement and manager self-efficacy", Journal ofManagement Development, 21(5), 376 - 387.

- Polatçı, S. (2011). Psikolojik Sermayenin Performans Üzerindeki etkisinde İş aile Yayilimi Ve Psikolojik İyioluşun Rolü, Unpublished Doctoral Thesis, Erciyes University.

- Polatc1, S. (2014). The Effects of Psychological Capital on Task and Contextual Performance: A Research on Police Organization. Ege Academic Review, 14(1), 115-124.

- Poon, J. M. L. (2013).Effects of benevolence, integrity, and ability on trust-insupervisor. Employee Relations 35(4), 396-407.

- Prieto, L. L. (2009). Exploring the Power of Self-efficacy at Work: Some Empirical Studies from the Social Cognitive Perspective, Unpublished Doctoral Dissertation, Universitat Jaume.

- Ratliff, M. R. (2012). Effect of Organizational Climate on Job Performance and Employee Engagement. Walden University, Psychology, Doctoral Philosophy.

- Rimm, H, and Jerusalem, M. (1999).Adaptation validation of an Estonian version of the General Self-Efficacy Scale (Eses). Anxiety, Stress \& Coping, 12(3), 329-345.

- Roberson, M. and Strickland, O. (2012). The Relationship Between Charismatic Leadership, Work Engagement, and Organizational Citizenship Behaviors. The Journal of Psychology, 144(3), 313-326.

- Robinson, D., Perryman, S., Hayday, S. (2004). The drivers of employee engagement. Institute of Employment Studies, UK.

- Rodopman, A. (1999). The Perception Of Core Job Characteristics By Turkish Employees, And Its Relation To Job Satisfaction, Unpublished Master Dissertation, Marmara University

- Rodriquez-Munoz, A., Sanz-Vergel, A. I., Demerouti, E., and Bakker, A. B. (2012). Reciprocal relationships between job demands, job resources, and recovery opportunities.Journal of Personnel Psychology, 11(2). 86-94.

- Ruppel, C. P. and Harrington, S. J. (2000).The relationship of communication, ethical work climate, and trust to commitment and innovation. Journal of Business Ethics, 25(4), 313-328.

- Saks, A.M. (2006). Antecedents and consequences of employee engagement. Journal of Managerial Psychology, 21(7), 600-619.

- Salanova, M. Grau, R., Llorens, S., and Schaufeli, W.B. (2001). Exposición a las tecnologías de la información, burnout y engagement: el rol modulador de la autoeficacia profesional (Exposure to information technology, burnout and engagement: about the role of professional self-efficacy). Psicología Social Aplicada, 11, 69-89.

- Salanova, M., Brescó, E. and Schaufeli, W.B. (2003). Hacia un modelo espiral de la autoeficacia en el estudio del burnout y engagemen [Towards a spiral 
model of self-efficacy in the study of burnout and engagement]. Submitted for publication.

- Salanova, M., Carrero, V., Pinanzo, D., and Schaufeli, W.B. (2003). Job characteristics and proactive behaviour: The mediating role of job engagement. Submitted for publication.

- Schaufeli, W. B. Salanova, M. Gonzalez-Roma, V. and Bakker, A. B. (2002). The measurement of engagement and burnout: A two sample confirmatory analytic approach. Journal of Happiness Studies, 3, 71-92.

- Schaufeli, W. B., Bakker, A. B. and Salanova, M. (2006). The measurement of work engagement with a shortquestionnaire: A cross-national study. Educational and Psychological Measurement, 66(4), 701-716.

- Schaufeli, W. B., Salanova, M., Gonzalez-Roma V. and Bakker, A. B. (2002). The measurement of engagement and burnout: A two sample confirmatory factor analytic approach. Journal of Happiness Studies, 3, 71-92.

- Schaufeli, W.B., and Bakker, A.B. (2004). Job demands, job resources, and their relationship with burnout and engagement: a multi-sample study. Journal of Organizational Behavior, 25, 293-315.

- Schaufeli, W.B., Bakker, A.B. (2003). UWES-Utrecht work engagement scale: test manual. Department of Psychology, Utrecht University.

- Schaufeli, W.B., Taris, T.W., and Van Rhenen, W. (2003). Workaholism, burnout and engagement: Three of a kind or three different kinds of employee well-being? Submitted for publication.

- Schönherr, A. (2011) "Über den Zusammenhang von Diversity-Klima, soziomoralischem Klima, Arbeitsengagement und Sinnerleben im Beruf', (About the Relation between Diversity Climate, Socia-moral Climate, work engagement and sense making at work), Unpublished Doctoral Thesis, Universität Innsbruck.

- Schwarzer R, and Schroder K. E. E. (1997). Effects of self-efficacy and social support on postsurgical recovery of heart patients. Irish Journal of Psychology, $18,88-103$.

- Schwarzer, R. (Ed.). (1992). Self-efficacy: Thought control of action. Washington, DC: Hemisphere.

- Schwepker, C. H., Schultz, R. J. (2013),"The impact of trust in manager on unethical intention and customer-oriented selling", Journal of Business \& Industrial Marketing, 28(4). 347 - 356.

- Sekaran, U. (2003). Research Methods for Business: A skill building approach. New Jersey: Wiley and Sons, Inc.

- Seo, E.H. (2013). A comparison of active and passive procrastination in relation to academic motivation. Social Behavior \& Personality: An International Journal, 41(5), 777-784.

- Shantz, A. Alfes, K. Truss, C. and Soane, E. (2013).The role of employee engagement in the relationship between job design and task performance, citizenship and deviant behaviours. The International Journal of Human Resource Management, 24(13), 2608-2627.

- Shuck, B. Reio, T. G. and Rocco, T. (2011). Employee engagement: an examination of antecedent and outcome variables, Human Resource Development International, 14(4), , 427-445. 
- Staheli, N. (2013). The Role Of Leadership And Performance Measurement Systems In Employee Engagement. University Of Hawaii, International Management, Doctoral Dissertation.

- Strom D. L., Sears K. L. and Kelly, M. K. (2014). "Work Engagement: The Roles of Organizational Justice and Leadership Style in Predicting Engagement Among Employees", Journal of Leadership and Organizational Studies, Vol. 21(1) 71-82.

- Sun, T. Zhao, X. W. Yang, L. B. and Fan, L. H. (2011). The impact of psychological capital on job embeddedness and job performance among nurses: a structural equation approach. Journal of Advanced Nursing 68(1), 69-79.

- Tan, H. H. Tan, C. S. F. (2000). Toward the differentiation of trust in supervisor and trust in organization. Genetic, Social, and General Psychology Monographs, 126(2), 241-260.

- Taştan, S. B. (2011). The Mediating Role of Psychological Empowerment on the Relationship between Participative Organizational Climate, Self-efficacy and Individual Performance Behaviors. Unpublished Doctorate Dissertation, Marmara University, Social Sciences Institute, Deparment of Business Administration (In English), Subdepartment of Organizational Behavior, İstanbul.

- Taştan, S. B. (2013). The Relationship Between Psychological Empowerment And Psychological Well Being: The Role Of Self-Efficacy Perception And Social Support. Öneri.C.10.S.40, 139-154.

- Taştan, S. B. (2014). The Theoretical Implications Of Job Demands-Resources Model: A Research Study On The Relations Of Job Demands, Supervisor Support And Job Autonomy With Work Engagement. Atatürk Üniversitesi İktisadi ve İdari Bilimler Dergisi, 28(4), pp.149-192.

- Thau, S.,Crossley, C. Bennett, R. J. and Sczesny, S. (2007). The Relationship between Trust, Attachment, and Antisocial Work Organizations. Human Relations, 60, 1155-1179.

- Tösten, R. and Özgan, H. (2014). Pozitif Psikolojik Sermaye Ölçeği: Geçerlik ve Güvenirlik Çalişmasi, Ekev Akademi Dergisi Y1l: 18 Sayı: 59.

- Turgut, T. (2011), "Çalışmaya Tutkunluk: İşyükü, Esnek Çalışma Saatleri, Yönetici Desteği ve İş-Aile Çatışmasi ile İlişkileri”, Atatürk Üniversitesi İktisadi ve İdari Bilimler Dergisi, 25(3-4).

- Uçanok, B. and Tevruz, S. (2008). The Effects Of Work Values, Work Centrality And Person-Job Fit On Organizational Citizenship Behavior. Marmara University, Organizational Behavior, Doctoral Dissertation.

- Ugwu, F. O. Onyishi, I. E. and Rodriguez-Sanchez, A. M. (2014). Linking organizational trust with employee engagement: the role of psychological empowerment. Personnel Review, 43(3), 377-400.

- Ünal, Z. M. and Turgut, T. (2013). "Birey-Örgüt Uyumunun Çalışan Tutkunluğuna Katkısı", Örgütsel Davraniş Kongresi Bildiriler Kitabi, Sakarya Üniversitesi, pp. 215-221.

- Vybornova, S. S., (2014). The Impact of Job Design on Job Satisfaction, Unpublished Doctoral Dissertation, University of Wyoming, Department of Administration.

- Wagnild, G. M. and Young, H. M. (1993). Development and Psychometric Evaluation of the Resilience Scale, Journal of Nursing Measurement, 1(2), pp. 165-178. 